\title{
PREDICTION OF ELEMENT TRANSFER USING RECYCLED SLAG IN SUBMERGED ARC WELDING
}

\author{
DEEPANJALI NIMKER* \& REETA WATTAL
}

Mechanical Engineering Department, Delhi Technological University, Delhi, India

ABSTRACT
The transfer of elements $C, M n, S i, S$ and P into the weld metal has been studied using recycled slag. Arc voltage, wire feed
rate, travel speed and nozzle to plate distance were selected as four independently controllable input factors. The
significance of the model was tested by analysis of variance (ANOVA) technique; effects of input variables arc voltage and
wire feed rate were studied on responses $\% \mathrm{C}, \% \mathrm{Mn}, \% \mathrm{Si}, \% \mathrm{~S}$ and $\% \mathrm{P}$. These models were then checked for adequacy
using ' $F$ ' test. It was observed that the transfer of $C, M n$ and $P$ was directly related to arc voltage whereas it was inversely
related to the wire feed rate. Moreover, the transfer of Si decreased with increase in wire feed rate, but remained constant
with varying arc voltage, welding speed and nozzle to plate distance. Furthermore, it was noticed that welding speed and
Nozzle to plate distance have a negligible influence on weld metal chemistry. It can be concluded that recycled slag gives
satisfactory results and can be used as a fresh flux.
KEYWORDS: Recycled slag, ANOVA, ' $F$ ' test

Received: Feb 15, 2021; Accepted: Mar 05, 2021; Published: Mar 24, 2021; Paper Id.: IJMPERDAPR202130

\section{INTRODUCTION}

An arc welding process, which uses an arc struck between the electrode and work piece to melt the weld metal under a blanket of flux is known as submerged arc welding (SAW). This flux blanket prevents weld metal from atmospheric contamination and converts into slag after welding. This slag is treated as a waste and discarded. SAW is widely used in the fabrication of pipelines and pressure vessels due to its high deposition rate, invisible arc, minimum spatter and less skilled labour requirement. With the use of SAW in various applications, a huge amount of flux is consumed and thus slag is dumped as waste. It was found that the amount of flux consumed produces an equal amount of slag during welding.

Few researchers have worked in the field of slag recycling. In 1976, it was estimated that approximately 1 $\mathrm{kg}$ of flux consumed with an equal amount of weld deposit [1]. With the increase in SAW applications, flux consumption rose from 2500 tonnes to 10000 tonnes in India during 1982-2006 [2-3]. Reclamation of slag was first attempted by using a closed-loop recycling process, but it was not accepted by the fabricators due to its deviation from American Welding Society (AWS) and American Society of Mechanical Engineers (ASME) standards. The development of technology for recycling of slag was first observed in Paton electric welding institute [4]. It was also found that if the slag is processed as per AWS and ASME standards then it can be proved reliable and repeatable commercially [5]. Later, it was reported that reclaiming and reuse of the fused slag helps in decreasing cost of SAW of titanium [6].

Literature describes that plenty of work had been done to study the influence of parameters on weld bead geometry during SAW. Slag mix \% was taken as a process parameter to study the significant effects of weld bead 
geometry [7]. In addition to this, recycled slag can produce satisfactory bead geometry shape relationship and microstructure of the weld metal [8-9]. Replenishing the recycled slag can also be possible by adding suitable deoxidisers and alloying element by agglomeration Also, slag flux mixture with $60 \%$ slag was used to evaluate the mechanical properties of weld metal. This composition passed visual inspection, dye penetration and radiographic tests. [10-11]. Replenished slag results in satisfactory mechanical properties as per AWS standards [12].

Several studies related to the element transfer behaviour in SAW using recycled slag found that flux composition and the weld metal inclusion were the main causes for the complex changes in SAW. Current thermodynamics theory of slag metal reaction shows that net transfer of oxygen is independent of Mn and Si transfer to the weld metal [14]. Mohan and Pandey [15] reported that weld chemistry and element transfer of manganese, silicon, carbon and sulphur was influenced by SAW parameters and flux basicity index. Sahni et al. [16] concluded that the open-circuit voltage, welding wire feed rate and basicity index have a predominant effect on the weld metal composition. Slag generated during welding can be recycled and used with varying proportions of flux. The slag-flux mix influences the chemistry of weld metal satisfactorily. Some of the studies found that it is possible to predict element transfer of $\mathrm{C}, \mathrm{Mn}, \mathrm{Si}$ and $\mathrm{S}$ by developing suitable regression models with the help of statistical designs of mixture experiments [17]. Wang et al. [18] investigated the effect of wire feed rate and welding current on metal transfer along with its arc behaviour. The transfer of $\mathrm{C}, \mathrm{Si}, \mathrm{Mn}, \mathrm{S}$ and $\mathrm{P}$ using formulated flux was achieved by extreme vertices design which developed an adequate mathematical model using ' $F$ ' test and ' $t$ ' test. This study can be followed by developing the model using half factorial design and checking the adequacy of the model by ANOVA technique [19-20].

The literature review mentioned is very useful for further research in this field. It was observed that a very few researchers have worked on recycling of slag so far. In the current study, an attempt has been made to predict $\% \mathrm{C}, \% \mathrm{Mn}$, $\% \mathrm{Si}, \% \mathrm{~S}$ and $\% \mathrm{P}$ transfer in submerged arc welding using recycled slag.

\section{EXPERIMENTATION}

Plan of experimentation begins with the process of slag recycling. Later, the process parameters along with their upper and lower limits were identified. Arc voltage, wire feed rate, travel speed and nozzle to plate distance with their limits was shown in Table 1. Experiments were performed using a two-level half factorial design matrix, where 8 sets of runs were performed randomly using submerged arc welding set-up shown in Figure 1. After conducting the experiments, the spectro analysis of the weld specimens was performed. Table 2 shows the results of the experimentation performed as per design matrix. 


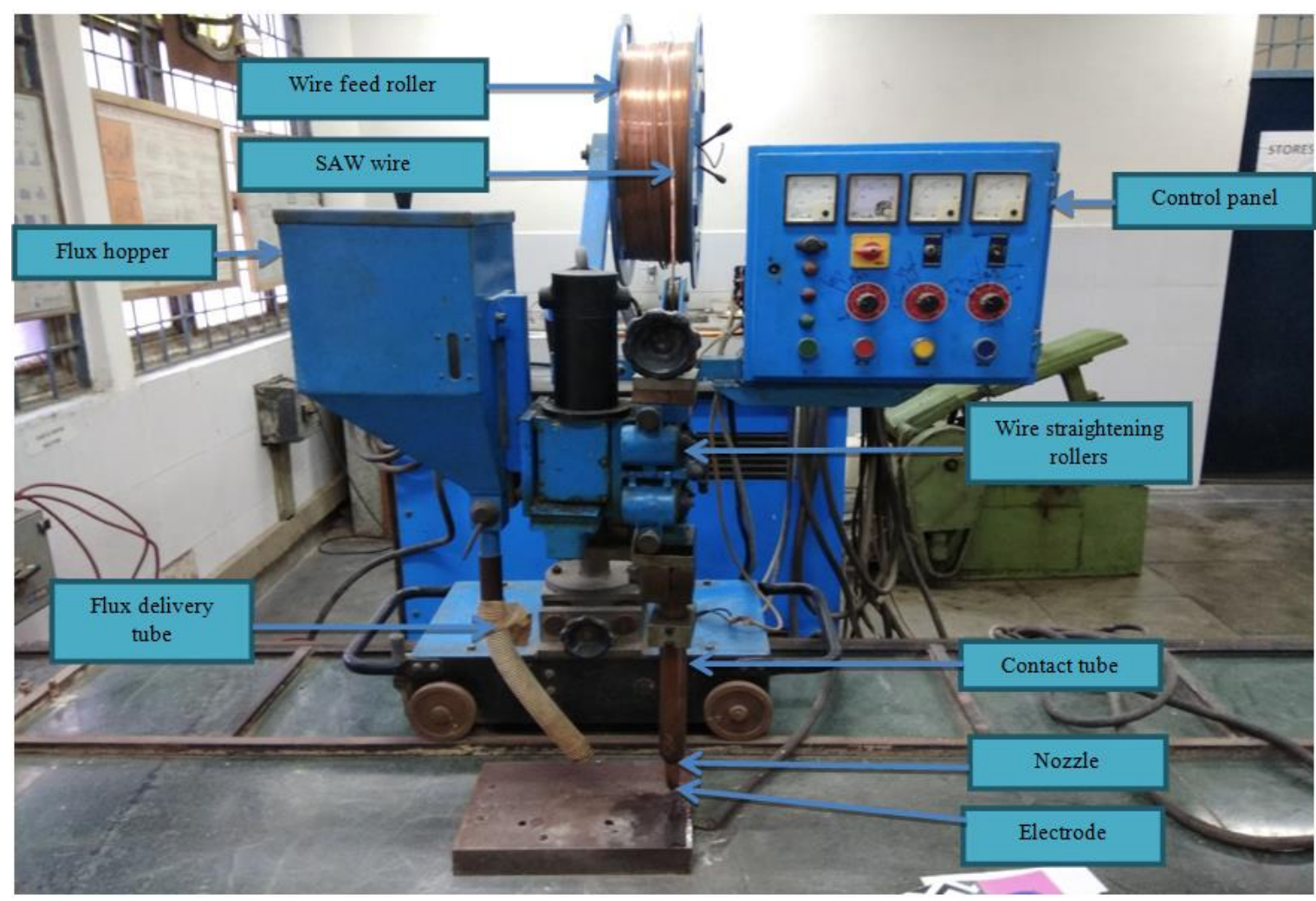

Figure 1: Submerged Arc Welding Setup

Table 1: Welding Input with Their Upper and Lower Limits

\begin{tabular}{|c|c|c|c|c|}
\hline Parameters & Units & Symbol & Low (-1) & High (+1) \\
\hline Arc Voltage & Volts & V & 25 & 40 \\
\hline Wire Feed Rate & $\mathrm{cm} / \mathrm{min}$ & $\mathrm{F}$ & 111 & 156 \\
\hline Travel Speed & $\mathrm{cm} / \mathrm{min}$ & $\mathrm{S}$ & 30 & 40 \\
\hline NTD & $\mathrm{mm}$ & $\mathrm{D}$ & 20 & 25 \\
\hline
\end{tabular}

Table 2: Results of Experimentation Performed as per Design Matrix

\begin{tabular}{|c|c|c|c|c|c|c|c|c|c|}
\hline Run & $\mathbf{V}$ & $\mathbf{F}$ & $\mathbf{S}$ & $\mathbf{D}$ & $\begin{array}{c}\text { Carbon } \\
(\boldsymbol{\%})\end{array}$ & $\begin{array}{c}\text { Manganese } \\
(\boldsymbol{\%})\end{array}$ & $\begin{array}{c}\text { Silicon } \\
(\boldsymbol{\%})\end{array}$ & $\begin{array}{c}\text { Sulphur } \\
(\boldsymbol{\%})\end{array}$ & $\begin{array}{c}\text { Phosphorus } \\
(\boldsymbol{\%})\end{array}$ \\
\hline $\mathbf{1}$ & 25 & 111 & 30 & 20 & 0.80 & 0.81 & 0.34 & 0.034 & 0.037 \\
\hline $\mathbf{2}$ & 40 & 111 & 30 & 25 & 0.86 & 0.86 & 0.31 & 0.032 & 0.030 \\
\hline $\mathbf{3}$ & 25 & 156 & 30 & 25 & 0.83 & 0.80 & 0.19 & 0.028 & 0.027 \\
\hline $\mathbf{4}$ & 40 & 156 & 30 & 20 & 0.069 & 1.13 & 0.29 & 0.033 & 0.027 \\
\hline $\mathbf{5}$ & 25 & 111 & 40 & 25 & 0.099 & 0.85 & 0.30 & 0.034 & 0.038 \\
\hline $\mathbf{6}$ & 40 & 111 & 40 & 20 & 0.060 & 0.87 & 0.33 & 0.030 & 0.029 \\
\hline $\mathbf{7}$ & 25 & 156 & 40 & 20 & 0.065 & 0.96 & 0.27 & 0.029 & 0.028 \\
\hline $\mathbf{8}$ & 40 & 156 & 40 & 25 & 0.072 & 1.05 & 0.31 & 0.025 & 0.026 \\
\hline
\end{tabular}

Equation 1, 2 and 3 were formulated to develop a relationship between the responses and input parameters. The adequacy of the above-mentioned mathematical models was checked using ANOVA. Table 3 presents the model adequacy test for various responses. Figure 2 to 7 illustrates graphs along with surface plots to explain the effect of input parameters on responses such as $\% \mathrm{C}, \% \mathrm{Mn}, \% \mathrm{Si}, \% \mathrm{~S}$ and $\% \mathrm{P}$.

The expression for response function is given as: 
$\mathrm{Y}=\mathrm{f}(\mathrm{V}, \mathrm{F}, \mathrm{S}, \mathrm{D})$

Where, Y- Response parameter, V - Arc Voltage, F - Wire feed rate, S - Travel speed, D - Nozzle to plate distance

Assuming linear relationship, the possible two-factor interactions were taken into consideration, therefore, the above expression rewritten as:

$Y=b_{0}+b_{1} V+b_{2} F+b_{3} S+b_{4} D+b_{12} V F+b_{13} V S+b_{14} V D+b_{23} F S+b_{24} F D+b_{34} S D$

After confounding, the given mathematical model can be expressed as:

$\mathrm{Y}=\mathrm{b}_{0}+\mathrm{b}_{1} \mathrm{~V}+\mathrm{b}_{2} \mathrm{~F}+\mathrm{b}_{3} \mathrm{~S}+\mathrm{b}_{4} \mathrm{D}+\mathrm{b}_{5}(\mathrm{VF}+\mathrm{SD})+\mathrm{b}_{6}(\mathrm{VS}+\mathrm{FD})+\mathrm{b}_{7}(\mathrm{VD}+\mathrm{FS})$

Table 3: Model Adequacy Test for Various Responses

\begin{tabular}{|l|c|c|c|c|c|c|c|c|}
\hline $\begin{array}{c}\text { Response } \\
\text { Parameters }\end{array}$ & \multicolumn{2}{|c|}{$\begin{array}{c}\text { Degree of } \\
\text { Freedom }\end{array}$} & $\begin{array}{c}\text { Variance of } \\
\text { Optimisation } \\
\text { Parameter }\end{array}$ & $\begin{array}{c}\text { Standard } \\
\text { Deviation of } \\
\text { Coefficient }\end{array}$ & $\begin{array}{c}\text { Variance of } \\
\text { Adequacy }\end{array}$ & $\begin{array}{c}\text { F- } \\
\text { Ratio } \\
\text { Model }\end{array}$ & $\begin{array}{c}\text { F Ratio } \\
\text { from } \\
\text { Table }\end{array}$ & $\begin{array}{c}\text { Model } \\
\text { Whether } \\
\text { Significant }\end{array}$ \\
\hline & $\boldsymbol{S}_{\boldsymbol{y}}^{\mathbf{2}}$ & $\boldsymbol{S}_{\boldsymbol{a d}}^{\mathbf{2}}$ & $\boldsymbol{S}_{\boldsymbol{y}}^{\mathbf{2}}$ & $\boldsymbol{S}_{\mathbf{b j}}$ & $\boldsymbol{S}_{\boldsymbol{a d}}^{\mathbf{2}}$ & & & \\
\hline Carbon & 8 & 3 & 0.000015 & 0.001403 & 0.000042 & 2.80 & 4.12 & Yes \\
\hline Manganese & 8 & 3 & 0.0024 & 0.17589 & 0.0066 & 2.67 & 4.12 & Yes \\
\hline Silicon & 8 & 3 & 0.00095 & 0.0108972 & 0.00253 & 2.60 & 4.12 & Yes \\
\hline Sulphur & 8 & 3 & 0.00000775 & 0.0009842 & 0.00002067 & 2.68 & 4.12 & Yes \\
\hline Phosphorus & 8 & 3 & 0.0000075 & 0.00096824 & 0.00002 & 2.67 & 4.12 & Yes \\
\hline
\end{tabular}

\section{RESULTS \& DISCUSSIONS}

Based on the adequacy of a model achieved, the model diagnostics were performed which explains how well the model fits. The diagnostics involve various plots such as the normal plot of residuals vs. internally studentized, predicted vs. actual, residual vs. run, DFFITS vs. run, DFBETAS for intercept vs. run, and a plot showing the interaction of responses with various input parameters. Figures $2 \mathrm{a}$ to $2 \mathrm{e}$ show normal plot residual vs. internally studentized for carbon, manganese, silicon, sulphur and phosphorus, respectively. Figures $2 \mathrm{a}$ to $2 \mathrm{e}$ clarify the extent to which the residuals points follow a straight line which indicates the normal distribution of residuals. The responses such as carbon, manganese, silicon and sulphur give a moderate scatter of points except phosphorus which shows the uneven distribution of points that surrounds a straight line.

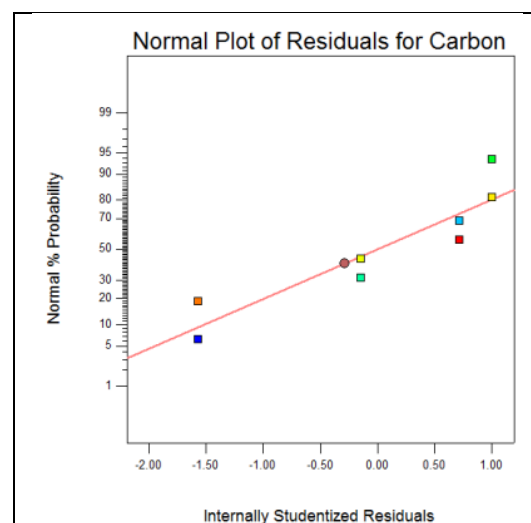

(a)

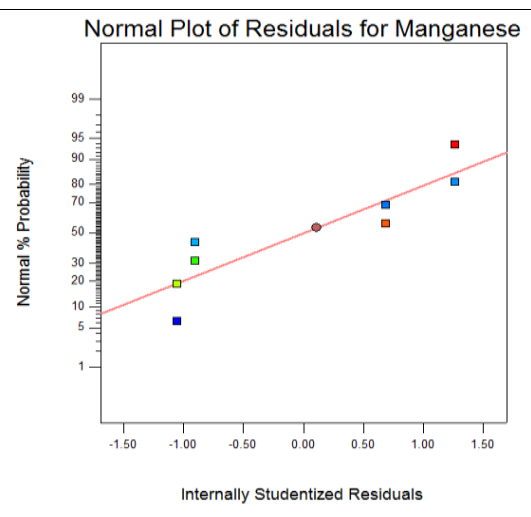

(b)

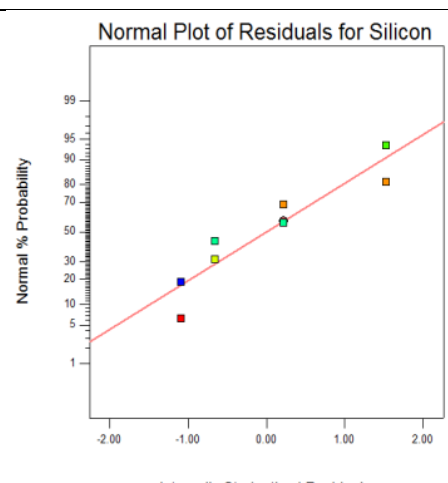

(c) 


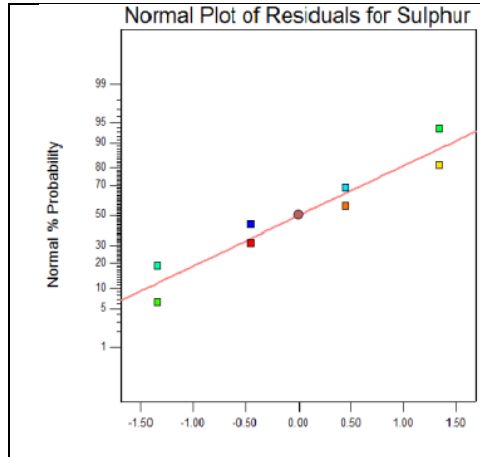

(d)

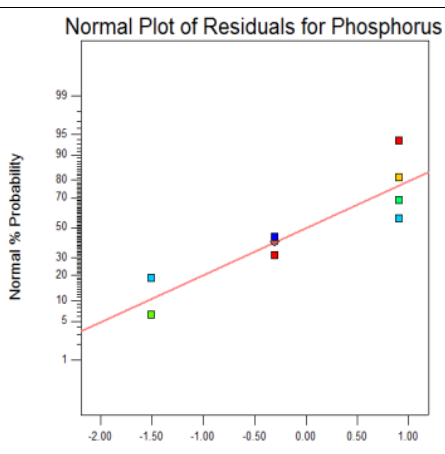

(e)

Figure 2: Normal Plot Residual vs. Internally Studentized for (a) Carbon (b) Manganese (c) Silicon (d) Sulphur (e) Phosphorus

Figure $3 \mathrm{a}$ to $3 \mathrm{e}$ shows predicted vs. actual plot for carbon, manganese, silicon, sulphur and phosphorus, respectively. As illustrated in figure 3a, carbon content increased from 0.060 to 0.099 with almost all the points achieved was near-predicted values. As presented in figure 3b, manganese content changed from 0.08 to 1.13 with all the points observed (actual) close to predicted values. As shown in figure 3c, silicon content varied from 0.19 to 0.34 and the points were almost same as that of predicted values. As shown in figure $3 \mathrm{~d}$, sulphur content changing from 0.025 to 0.035 and figure 3 e elaborated the phosphorus content fluctuating from 0.026 to 0.038 .

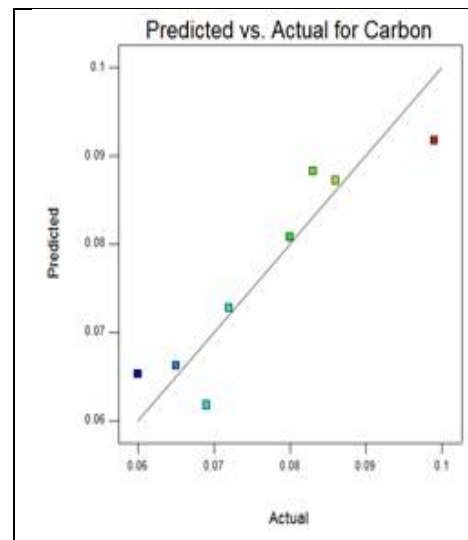

(a)

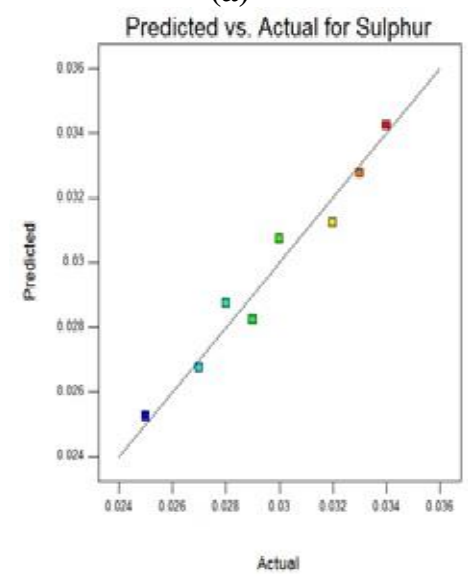

(d)

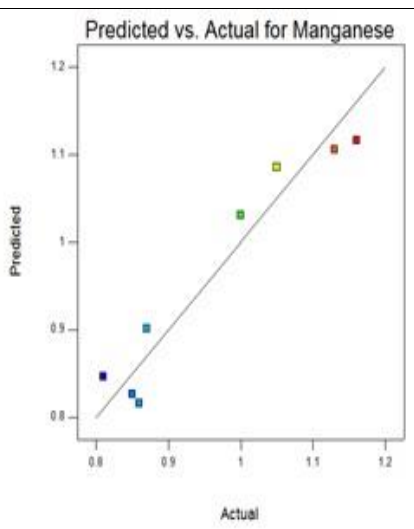

(b)

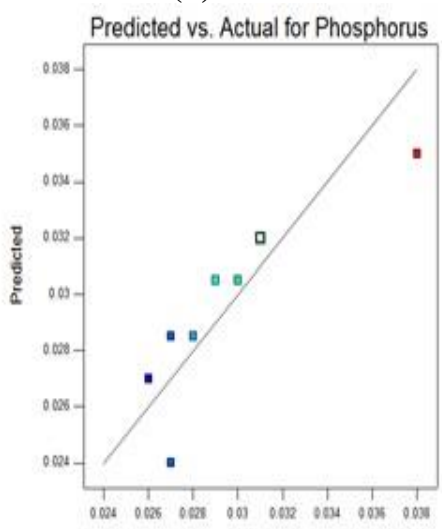

(e)

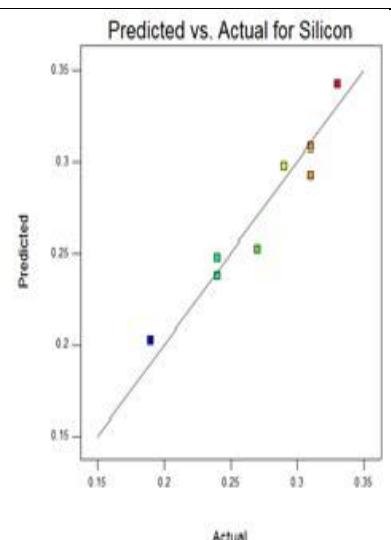

(c)

Figure 3: Predicted vs Actual Plot for (a) Carbon (b) Manganese (c) Silicon (d) Sulphur (e) Phosphorus 
Figure $4 \mathrm{a}$ to $4 \mathrm{e}$ illustrated residual vs. run plot for carbon, manganese, silicon, sulphur and phosphorus, respectively. Here, the various terms tend to distribute above and below regression line $=0$. Since the terms lie within the range, it suggests a linear relationship among the residual values. As shown in figure 5a to 5e, DFFITS vs. run plot were presented graphically for carbon, manganese, silicon, sulphur and phosphorus, respectively. In order to measure the effect of model terms on fitted terms, this plot plays a vital role. As depicted in figure 6a to 6e, DFBETAS for intercept vs. run for carbon, manganese, silicon, sulphur and phosphorus respectively were plotted. These plots explain the impact of particular term on each estimated regression factors, the DFBETAS value lies within the range from +2.37 to -2.37 , thus suggests the model is adequate.

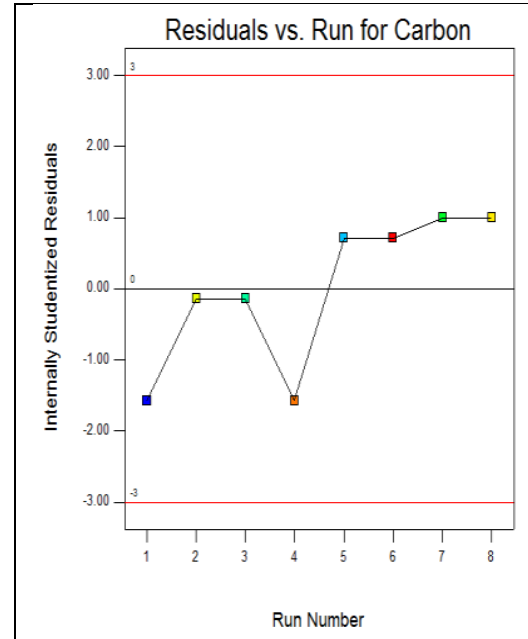

(a)

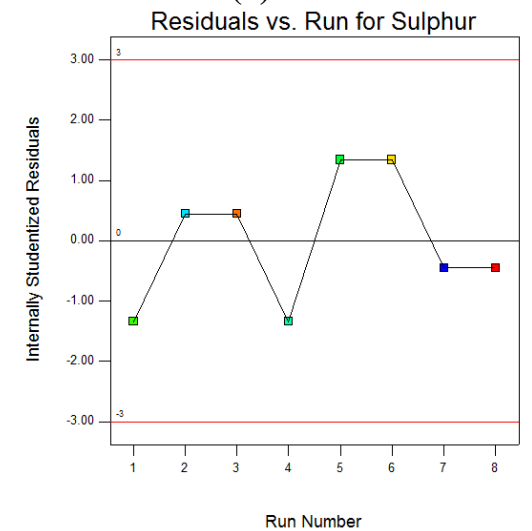

(d)

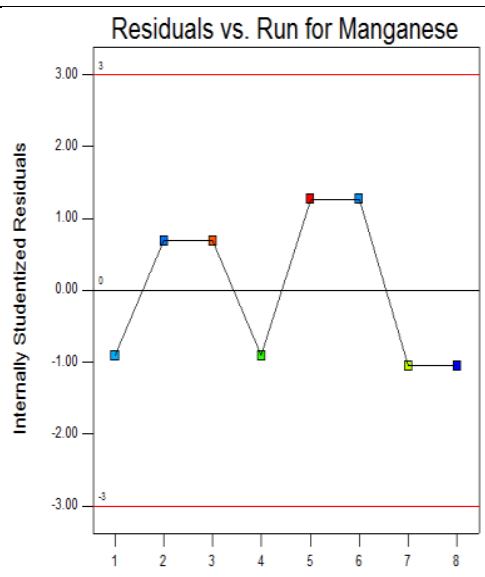

(b)

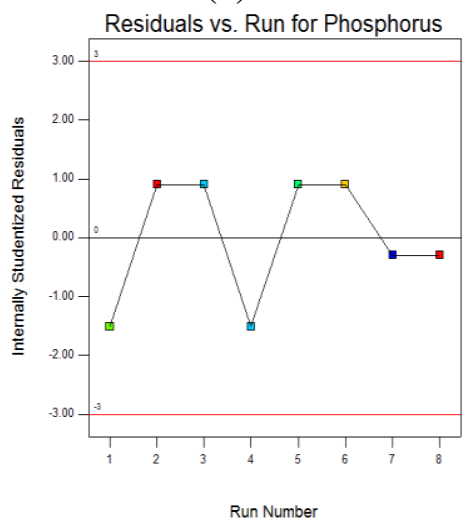

(e)

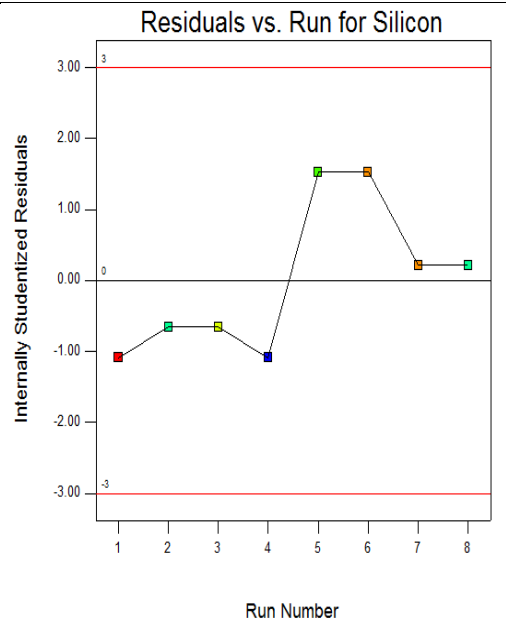

(c)

Figure 4: Residual vs Run Plot for (a) Carbon (b) Manganese (c) Silicon (d) Sulphur (e) Phosphorus 


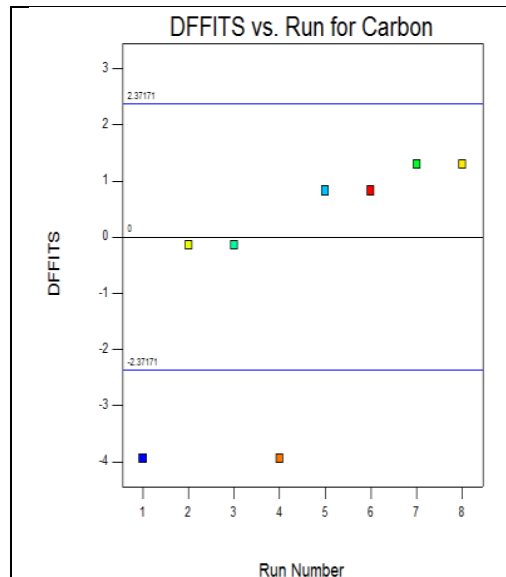

(a)

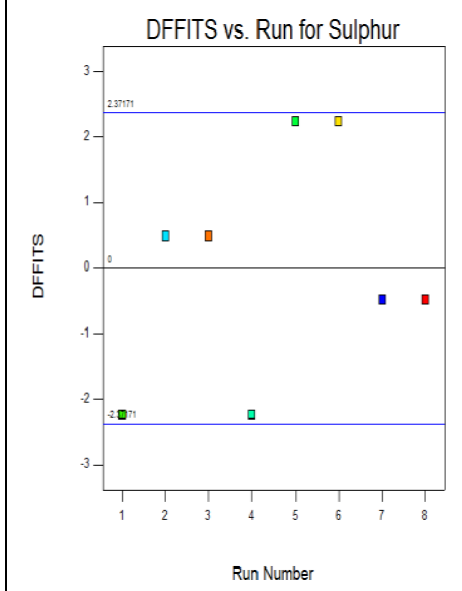

(d)

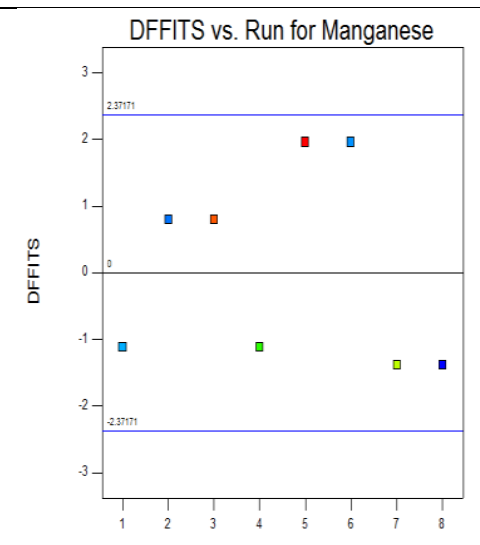

Run Number

(b)

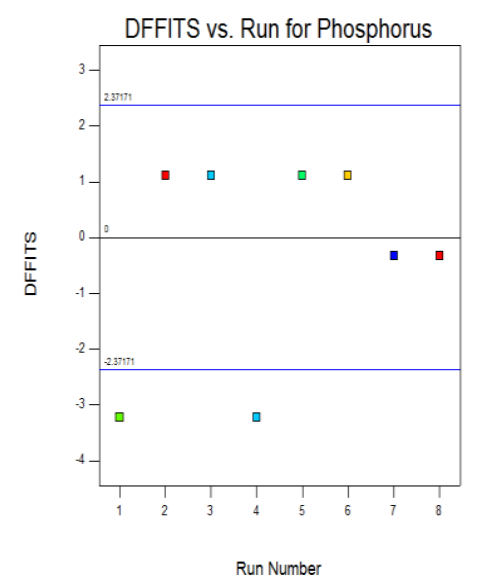

(e)

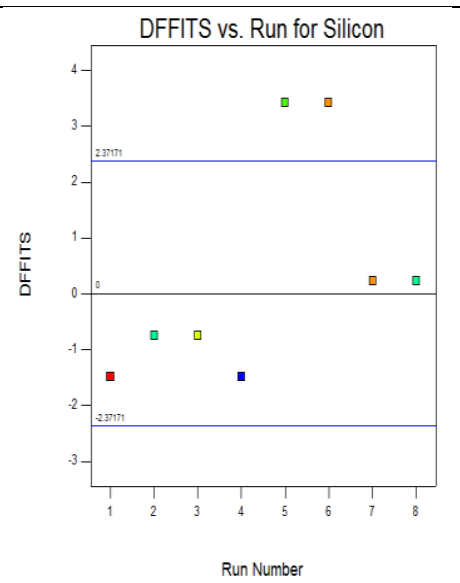

(c)

Figure 5: DFFITS vs. Run Plot for (a) Carbon (b) Manganese (c) Silicon (d) Sulphur (e) Phosphorus

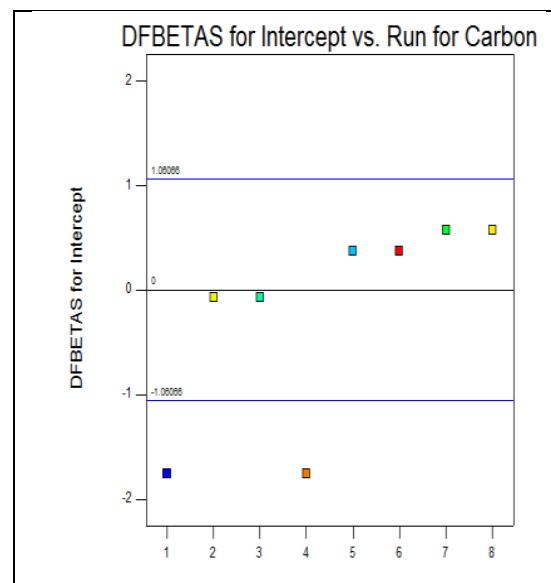

(a)

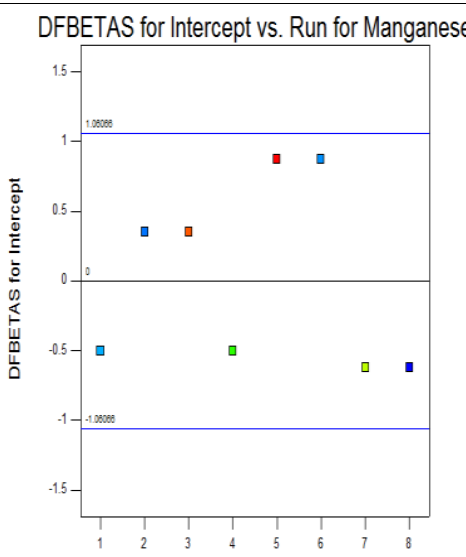

(b)

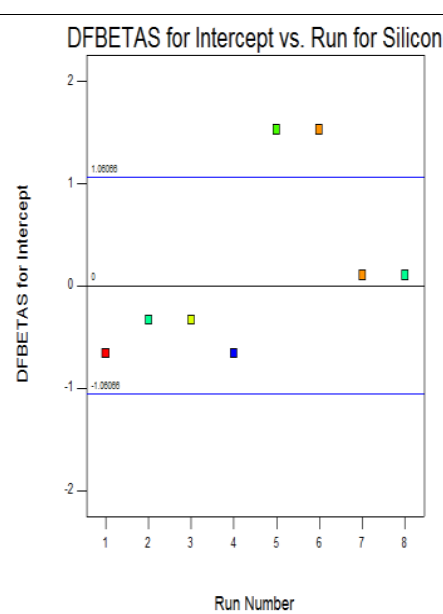

(c) 


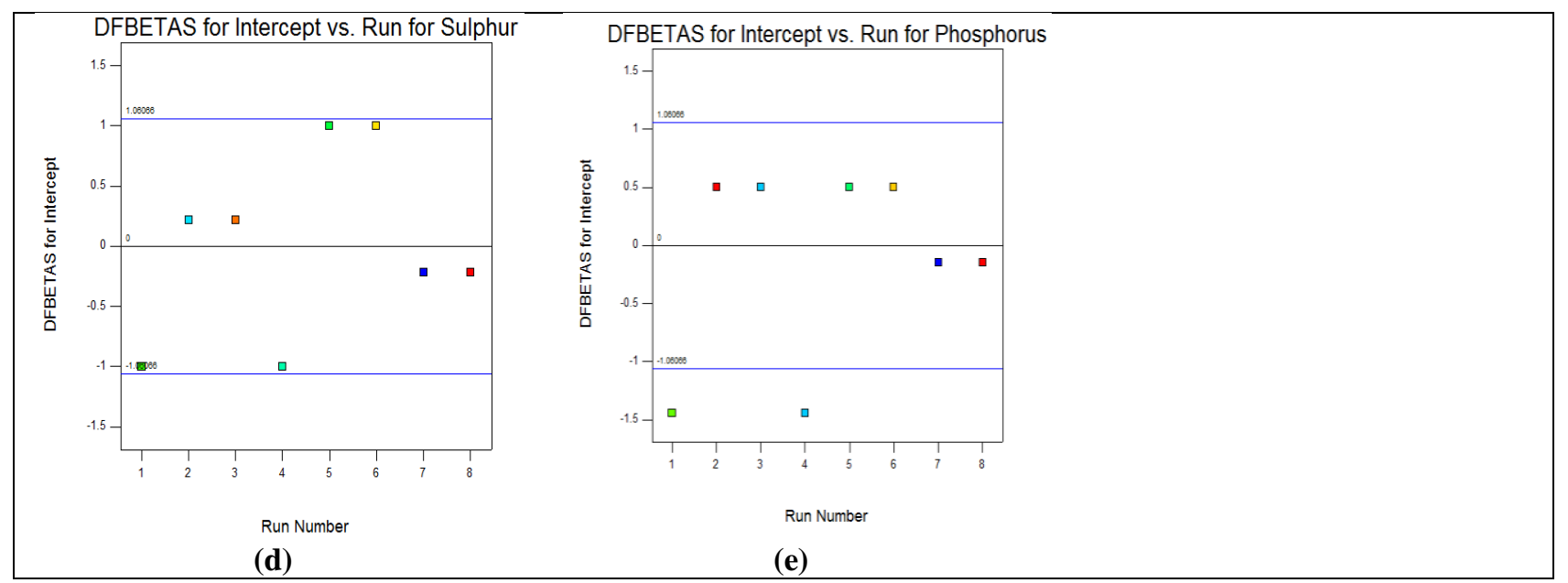

Figure 6: DFBETAS for Intercept vs Run for (a) Carbon (b) Manganese (c) Silicon (d) Sulphur (e) Phosphorus

As mentioned in figure 7a to 7e, these graphs presented the influence of arc voltage and wire feed rate on carbon, manganese, silicon, sulphur and phosphorus respectively. Moreover, the interaction effect was presented using 3D surface plot. Figure 7a demonstrated the interaction effect of arc voltage and wire feed rate on carbon content. It was observed that carbon content increased linearly (from 0.060 to 0.099) with arc voltage, whereas it acts inversely with the wire feed rate. In figure $7 b$, it was observed that manganese content rose (from 0.81 to 1.13 ) with the rise in arc voltage, whereas it acts the opposite in case of wire feed rate. In figure 7 c, it was observed that Silicon content (varies from 0.19 to 0.34) reduces with an increase in wire feed rate. As mentioned in figure 7d, sulphur content fluctuates (from 0.025 to 0.035 ) with varying arc voltage and wire feed rate. Therefore, it was concluded that sulphur content was inversely related to the wire feed rate, whereas it was not affected by the arc voltage. In Figure 7e, it was shown that phosphorus content (ranges from 0.026 to 0.038 ) rose with the rise in arc voltage, whereas in case of wire feed rate it acts inversely.

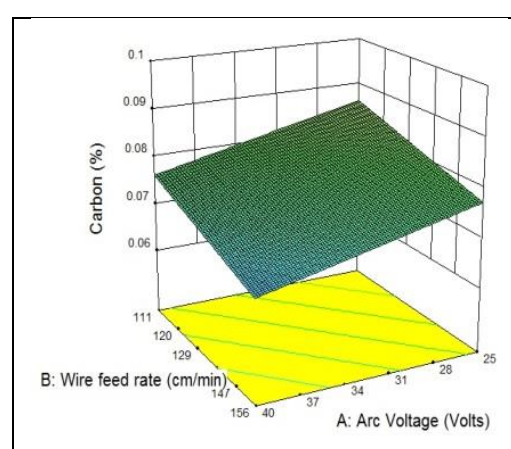

(a)

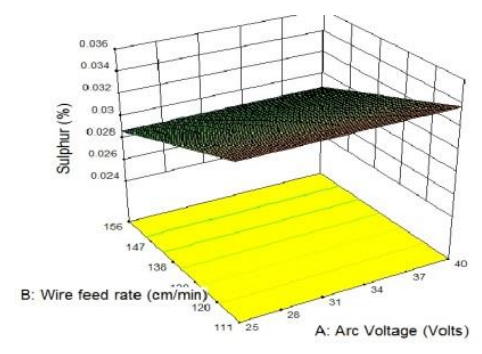

(d)

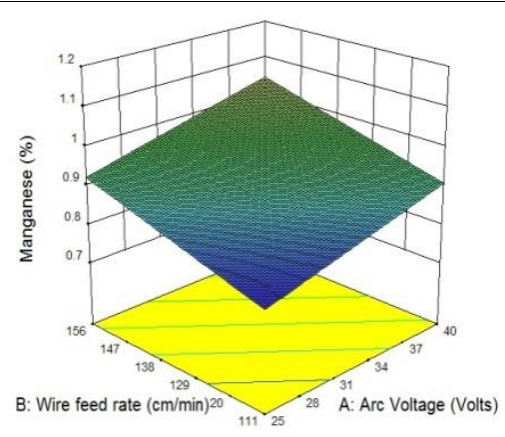

(b)

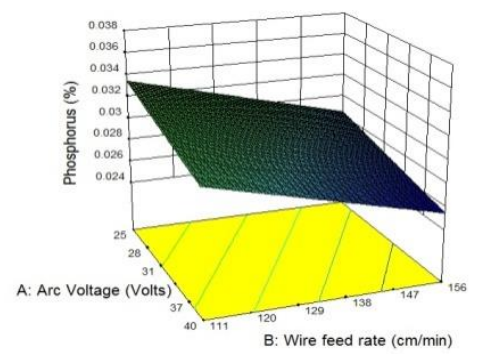

(e)

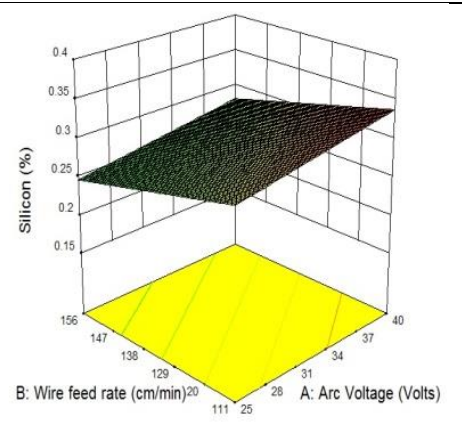

(c)

Figure 7: Interaction Effect of Arc Voltage and Wire Feed Rate for (a) Carbon (b) Manganese (c) Silicon (d) Sulphur (e) Phosphorus 


\section{CONCLUSIONS}

- Carbon content increased with an increase in arc voltage, whereas it decreased with an increase in wire feed rate. Both welding speed and nozzle to plate distance have negligible effect on it.

- Manganese content increased with an increase in arc voltage, whereas it decreased with an increase in wire feed rate.

- Silicon content decreased with an increase in wire feed rate, but remains constant with varying arc voltage, welding speed and nozzle to plate distance.

- Sulphur content decreased with an increase in wire feed rate, but remains the same with varying arc voltage, welding speed and nozzle to plate distance.

- Phosphorus content increased abruptly with an increase in arc voltage and decreased with the increase in wire feed rate, but remains almost near to constant in case of nozzle to plate distance and welding speed.

- It was concluded that nozzle to plate distance have negligible effect on weld metal chemistry.

\section{REFERENCES}

1. Weisman C. (1976) AWS Welding Hand book, 7th Edition, Miami, USA, American Welding Society.

2. Visvanath P.S. (1982) Submerged Arc Welding Fluxes. Indian Welding Journal, Vol. 15 (1), pp 27-30.

3. Honavar D.S. (2006) Cost effective productivity in welded fabrication. Technology Trends. September pp 13-6.

4. Beck H.P., Jackson A.R. (1996) Recycling SAW slag prove Reliable and Repeatable, Welding Journal, 6 (75), pp 51-54.

5. Chai C. S. and Eagar T. W. (1982) Slag-Metal Reactions in Binary CaF2-Metal Oxide Welding Fluxes. Welding Research Supplement, July: 229s-232s

6. Moi S. C., Bandyopadhyay A., Pal P. K. (2001) Submerged Arc Welding with a Mixture of Fresh Flux and Fused Slag. Proceedings of National Seminar on Advances in Material and Processing, IIT, Roorkee, India

7. Singh K., Pandey S., Arul M.R. (2005) Effect of Recycled Slag on Bead Geometry in Submerged Arc Welding. Proceedings of International Conference on Mechanical Engineering in Knowledge Age, December 12-14, Delhi College of Engineering, Delhi.

8. Singh J., Singh K. and Garg J. (2011) Reuse of Slag as a flux in submerged arc welding and its effect on chemical composition, bead geometry and microstructure of the weld metal, Int. J. Surf. Eng. Mat. Tech., 1 (1), 24-27.

9. Singh K. Singh J. (2010) Influence of Slag Flux Mixture on Mechanical Properties of Welds in Submerged Arc Welding". National Conference on Advancements and Futuristic Trends in Mechanical Engineering, February 19-20.

10. Singh K., Pandey S. and Mani R.A. (2006) Recycling of Submerged Welding Slag. Australasian Welding Journal 51(2), 34-38.

11. Sing, Jagmeet, and Jaspal Singh. "Sustainable Use of Industrial Waste in Cement Industry." International Journal of Environment, Ecology, Family and Urban Studies (IJEEFUS) ISSN (P) (2016): 2250-0065.

12. Singh K, Pandey S. 2009. (2009) Recycling of slag to act as a flux in submerged arc welding, Resources, Conservation and Recycling 53 552-558. 
13. Davies M.L.E, Bailey N. (1991) Evidence from Inclusion Chemistry of Element Transfer during Submerged Arc Welding”. Welding Journal 70(2), 57-65.

14. Reddy, K. Srinivasulu. "Optimization \& prediction of welding parameters and bead geometry in submerged arc welding." International Journal of Applied Engineering Research And Development 3.3 (2013): 1-6.

15. Mitra U., Eagar T.W. (1984) Slag metal reactions during submerged arc welding of alloy steels, Metallurgical Transaction A (15A) $217-227$.

16. Pandey S., Bharti N.D, Arulmani R., Gupta S.R. (1994) Effect of submerged arc welding parameters and fluxes on element transfer behaviour and weld-metal chemistry. Journal of Materials Processing Technology 40, 195-211.

17. Sharma, Meenu, and Shahnwaz Alam. "EXPERIMENTAL INVESTIGATION OF MECHANICAL PROPERTIES OF SAW WELDMENTS OF IS-2062 STEEL PLATES." International Journal of Mechanical and Production Engineering Research and Development (IJMPERD) 8, 4, Aug 2018, 1043-1048

18. Mohan N., Pandey S. (2005) Modelling for Element Transfer in Submerged Arc Welding. Proceedings of International Conference on Mechanical Engineering in Knowledge Age, December 12-14, Delhi College of Engineering, Delhi.

19. Sahni V., Singh K., Pandey S. (2009) Waste to Wealth: Reuse of Slag as a Flux in Submerged Arc. Welding Asian Journal of Chemistry Vol. 21, No. 10, S072-075.

20. Saluja, Rati, and K. M. Moeed. "Depiction of detrimental metallurgical effects in grade 304 austenitic stainless steel arc welds." International Journal of Mechanical and Production 8.6 (2018): 207218 (2018).

21. Kanjilal P., Pal T.K., Majumdar S.K. (2007) Prediction of Element Transfer in submerged arc welding. Welding Research Journal (86), 135-14

22. Wang J., Wu D., Liao P., Tian C.Y., Li M.Q, Feng J.C. (2014) Metal transfer and arc behaviour of novel consumable and nonconsumable electrode indirect arc droplet welding. Welding Journal Vol. 93, 431-438.

23. Fathi, Mohammed Shaalan Abed, Qayshazim Ismael, and Khalid Abbas Saleh. "AN EFFECT OF WELDING TYPE ON THE MECHANICAL PROPERTIES OF WELDING JOINTS." International Journal of Mechanical and Production Engineering Research and Development (IJMPERD) 9, 4, Aug 2019, 699-708

24. Jindal S., Chibber R., Mehta N.P. (2014) Prediction of element transfer due to flux and optimisation of chemical composition and mechanical properties in high-strength low-alloy steel. Proceedings of the Institution of Mechanical Engineers, Part B: Journal of Engineering Manufacture 229(5), 785-801

25. Montgomery D.C. (2006) Design and analysis of Experiments. Wiley-INDIA edition, New Delhi.

26. Rosli, Norana, et al. "INFLUENCE OF PROCESS PARAMETER ON THE HEIGHT DEVIATION OF WELD BEAD IN WIRE ARC ADDITIVE MANUFACTURING." International Journal of Mechanical and Production Engineering Research and Development (IJMPERD) 10, 3, Jun 2020, 1165-1176 